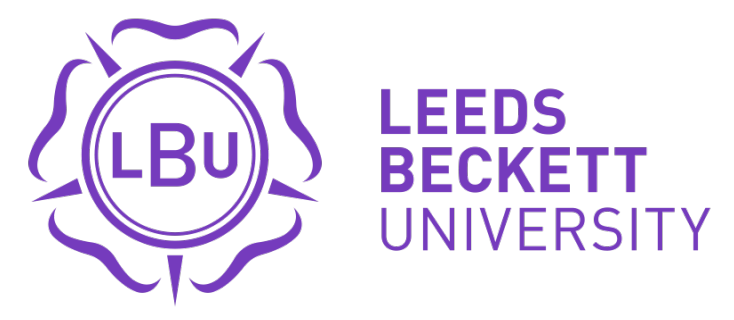

Citation:

Hylton, K (2014) Victoria Wolcott, Race, Riots and Roller Coasters: The Struggle over Segregated Recreation in America. Pennsylvania: University of Pennsylvania Press, 2012. 310pp. 17 figures. Bibliography. Index. £23.99 hbk. £17.77 Kin. Urban History, 41. 559 - 560 (2). ISSN 1469-8706 DOI: https://doi.org/10.1017/S0963926814000224

Link to Leeds Beckett Repository record:

https://eprints.leedsbeckett.ac.uk/id/eprint/18/

Document Version:

Article (Other)

The aim of the Leeds Beckett Repository is to provide open access to our research, as required by funder policies and permitted by publishers and copyright law.

The Leeds Beckett repository holds a wide range of publications, each of which has been checked for copyright and the relevant embargo period has been applied by the Research Services team.

We operate on a standard take-down policy. If you are the author or publisher of an output and you would like it removed from the repository, please contact us and we will investigate on a case-by-case basis.

Each thesis in the repository has been cleared where necessary by the author for third party copyright. If you would like a thesis to be removed from the repository or believe there is an issue with copyright, please contact us on openaccess@leedsbeckett.ac.uk and we will investigate on a case-by-case basis. 
Victoria Wolcott, Race, Riots and Roller Coasters: The Struggle over Segregated Recreation in America. Pennsylvania: University of Pennsylvania Press, 2012. 310pp. 17 figures. Bibliography. Index. £23.99 hbk. £17.77 Kin.

This book by Victoria Wolcott is an outstanding contribution to a history of recreation and leisure through the poorly documented lens of 'race' and race relations in North America in the twentieth century. The book is written in an accessible way using the device of everyday leisure time events to emphasise the way 'race' and racism played out in seemingly benign recreational spaces. The book is made up of six chapters that present a critical historical commentary on popular notions of a golden age of amusement parks, the resistance and struggles by organised groups and individual citizens that led up to and after the Civil Rights Acts 1964, and the decline of the amusement park and growth of the theme parks in response. The work not only draws on historical accounts of amusement and theme parks but also offers a critical social history that melds the dominant discourses of amusement parks with the civil rights tensions and struggles in America. Processes of everyday racism are illustrated here in a skilful assessment of how state sponsored, institutional and individual behaviours explicitly and implicitly reinforce racial hierarchies. While Wolcott uses recreation to challenge popular conceptions of spaces for fun and enjoyment, this re-visioning of amusement park history reflects a frontline for civil disturbances emanating from resistance to racial oppression manifest in bigotry, injustice and violence. Wolcott quotes protester James Farmer (p202) who said that the protests against recreational apartheid were trying to publicise, 
'The melancholy contrast between the idealized, fantasy world of the Fair and the real world of brutality, prejudice, and violence in which the American Negro is forced to live'

The work is well referenced with a set of very comprehensive endnotes, bibliography and index. What this means is that the book can be read by the non-academic wishing to engage in an informative text and the academic wanting to explore a more detailed history of racial segregation and the development of amusement parks. Wolcott uses hundreds of sources from police, media and available public records to piece together a highly persuasive socio-political view of history. Provocative parallels were drawn between Brown v, Board of Education, and the Civil Rights Act 1964 that forced public providers to offer their segregated facilities to all. The parallels that Wolcott draws out include the bids to subvert the law by those fervently against integration, the turns to violence and intimidation to support these expressions of bigotry and the resistance that this behaviour engendered from African Americans and their supporters.

Wolcott explores the historical development of amusement parks initially by describing the opportunistic responses to the development of urban spaces and transport hubs in America. Most of the amusement parks were situated close to racially mixed urban areas and yet they were often segregated and/or separate. Thus making amusement parks symbolic of the exclusion of African Americans. This was further exacerbated by whites only policies that were were reinforced through threats, violence, increased prices and private police forces. 
Resistance by the white owners of amusement parks is illustrated here through the measures and rationales for their support for segregation. Fears of racial mixing, the transmission of disease through inferior standards of hygiene, socialising and miscegenation, violence and black criminality. Post Civil Rights Act 1964 the clamber to designate previously public facilities as private members [whites] only clubs reached fever pitch. More dastardly and nefarious attempts were made to circumvent the spirit of the law for public facilities to be desegregated by trying to stay within its wording by arguing it no longer applied to them. Some went even further by leaving their facilities to fall into disrepair before selling off the land rather than run an integrated facility. Wolcott outlines how state providers openly flouted the law and at times provided police back up to support those who were also contravening legal directives. Wolcott's observation of the Disney style theme park having its origins in amusement park owners wishing to move further away from high density urban areas to force a 'whitening' of their customer base has a convincing basis in this socio-historical analysis that also incorporates an analysis of space and class to further inform its conclusions. Wolcott crafts a story that demonstrates how integrated amusement parks became symbols of black progress in America while taking the shine off the utopian notion of the 'fun' fair from both African American and white American perspectives.

Finally, Wolcott concludes that the popularity of amusement parks was based on a racial ideology of safe white spaces free of the African American presence. The shift to suburban theme parks was a reaction to 'integrated' urban amusement parks becoming associated with danger, gangs, and disorder, as 'race' and resistance played out culminating in violence, riots and deaths. Wolcott makes excellent observations 
about mythopoeic conceptions of recreation and a learned ignorance of the place of 'race' and racism in social history. This book is highly original and should find its way into libraries that pride themselves on mutlidisciplinarity. For a hardcover this book represents great value at just over $£ 20$ and at $£ 17$ it is also available in a Kindle format.

\section{K.D.F. Hylton}

Leeds Metropolitan University 